\title{
Influence of Customs and Traditions on the Process of Community Development Among Rural Communities in Enugu State, Nigeria
}

\author{
Charles, Nwoye E. $\quad$ Ledornu, Deekor H. (Ph.D) Daerego, Taylor I (PhD)* \\ Department of Adult Education \& Community Development, Faculty of Education, Rivers State University, \\ Nkpolu Oroworukwo, Port Harcourt, PO Box 5080 Rivers State, Nigeria
}

\begin{abstract}
This study examined the influence of customs and traditions on the process of community development among rural communities in Enugu state, Nigeria. Three research questions guided the study. The study adopted a descriptive survey design with a target population of 847 adults comprising 379 traditional rulers and 468 town union presidents in all the 468 communities in the 17 LGAs of Enugu State. The population was taken as a census with no sampling. The study used a self- designed questionnaire and a Focus Group Discussion Guide for data collection which were validated by experts. The internal consistency of the questionnaire was determined using the Cronbach Alpha statistics. The quantitative data collected were analysed using mean statistics and standard deviation while the qualitative data collected via Focus Group Discussion were analysed using content analysis. From the analysed qualitative and quantitative data, the findings of the study among others showed that the existing customs and traditions prevalent among the various communities in Enugu State, Nigeria are Adult circumcision (Ibe-Epi or Ibe-ugwu) Masquerade (Mmanwu), Age grade grouping (Uro-Ogbor or Otu-Ogbor), pouring of libation (Igor-Ofo), homage to the ancestral fathers' graves (Igba-Aju), the new yam festival (Iriji or Iwaji), Women August Meeting (Ogbako Umunwanyi Na-August), Soil festival-No farming sacred week (OririAni Na Nso-Ani), practice of caste system (Ohu or Osu), among others. It was also revealed that the influence of customs and traditions on the planning of community development programmes in Enugu State is evident in the fact that women were excluded from the decision making process in planning community development projects, community members reject projects to be sited in places the people consider forbidden, development programmes are not planned during festivals and the Women August meeting tradition is used as an avenue for planning of community development programmes. Based on the findings of the study, it was recommended among other things that traditional rulers should engage all the organized traditional structure (Igwe in-council, Elders council, women through August meeting platform, age grades and others) to do periodic planning of self-help development projects in their respective communities.
\end{abstract}

Keywords: Customs, Traditions, Community Development

DOI: $10.7176 / \mathrm{JEP} / 11-32-08$

Publication date: November $30^{\text {th }} 2020$

\section{Introduction}

Customs and traditions can be traced to the beginning of man's evolution. People in various settings over time set patterns of behaviour and norms that guided their everyday interaction and form the basis for assessing right or wrong behaviour. This has led to peculiar ways of doing things among different sets of people around the world which they refer to as their customs or traditions.

In Africa, traditions and customs are seen to be sacred. They are often presumed to be ancient, unalterable, and deeply important. They define acceptable standard of behaviour in most communities and people uphold these customs and traditions so highly, that breaking them or not adhering to them often lead to grave consequences such as being ostracized or in worst scenario, death. Supporting this, Deekor and Nnodim (2005) noted that communities all over the world especially in Africa hold tenaciously to their beliefs by which rational judgements are given to any action or inaction. It determines to a large extent what type of development efforts or programmes will be accepted by the people.

Tradition refers to beliefs or customs that are prehistoric, with lost or obscure origins, existing from time immemorial (Shills, 2013). Tradition is also seen as any established method or practice of doing things by a group of persons that is transmitted from one generation to the other (Deekor \& Nnodim, 2005). Originally, traditions were passed orally, without the need for a writing system. Tools that aided this process include poetic devices such as stories, rhyme and alliteration. The stories thus preserved are also referred to as tradition, or as part of an oral tradition. Even such traditions, however, are presumed to have originated (been "invented" by humans) at some point (Shils, 2013).

Custom on the other hand is used interchangeably with tradition. The Merriam- Webster dictionary defines it as an action or way of behaving that is usual and traditional among the people in a particular group or community. Crossman (2018) defined customs as a cultural idea that describes a regular, patterned way of behaving that is 
considered characteristic of life in a social system. Shaking hands, bowing and kissing are all customs. They are ways of greeting people that help to distinguish one society from another. Similarly, the Cambridge Dictionary defined customs as a way of behaving or a belief that has been established for a long time. In the same vein, Quora (2013) viewed customs as a certain repeated action that has become typical of a group of people and is handed down by parents or elders of a group or a tribe and often typifies that group. Customs help to maintain social harmony and unity within a community. If a law, practice or even development programme goes against established customs of a people, it may be difficult to uphold.

Green in Adekola and Nwoye (2016) asserted that traditions and customs in African societies are orally handed down from one generation to another. It is what defines a set of people as different from others. Each group of people has customs that are unique to them. For example, it is common to find among the people of Enugu State the practice of celebration of the new yam festival referred to as "iri ji" or "iwa ji". There is also the belief that the community is basically sacred, rather than secular and surrounded by several religious forms and symbols. This accounts for why most Igbos irrespective of where they reside, whether in urban cities or diaspora return home to identify with their communities especially in times of festivals.

Furthermore, it is worthy of note that these customs and traditions most times determine what type of development programme people will be willing to come out and support. If a particular programme does not align with the people's customs and traditions, there is a tendency that the people will vehemently oppose the programme or boycott such programmes. This negates the principle of community development which advocates the active participation of community members in programmes meant for them. This view was corroborated by Deekor and Nnodim, (2005) when they asserted that rural development programmes do not take place in a vacuum. They are meant for people either in the urban or rural communities. These communities have customs and traditions which are very formidable and act as the cementing factor that bind the people together and determine development efforts that will be acceptable. These customs and traditions determine whether a programme would be welcomed or not. For instance, it is the custom of the Biaga people of Central India that it is an act of wickedness to plough the soil with mould board plough as they regard the earth as a gentle mother. Also, it is believed that it in some parts of Ibo communities in Eastern Nigeria poor harvest signifies the anger of "Ahanjoku" the god of harvest (Deekor \& Nnodim, 2005).

Similarly, in Enugu State, Nigeria which is the area of this study, there has been cases where development efforts that do not conform to the people's customs and traditions were vehemently resisted even when such efforts were for the common good of all. For example, in December, 2013, Umuigbo-Amurri Atonomous community in Nkanu West Local Government Area, Enugu State, refused to release a particular land requested by Saint Mary Catholic Church Amurri for a technical school because they believe the land belonged to a particular deity where they go for traditional healing and worship during new yam festival. Such believes impede community development programmes.

Similarly, Imhabekhai (2009) noted that the campaign against female circumcision and genital mutilation that has been discovered to have health, sexual, marital and other hazards is still being resisted by some communities in the study area because most of the people who practise them believe they are part of the culture and traditions that must be preserved. Eze (2013) further explained the important role custom and tradition plays among the people of Enugu when he noted that locating a community development project in a land regarded as a forbidden soil by the people of Amurri in Nkanu West Local Government Area of Enugu State and the idea of initiation of birth control programmes in communities where children are perceived to be gifts from the gods will face some resistance from the people.

However, there are other aspects of the traditions and customs of the people of Enugu State that promote community development programmes. Notable among them is the activities of the women's wing of various communities popularly referred to as the "Women August Meeting". In this, women associations come together periodically to deliberate on issues bothering on the welfare of their communities. They identify priority areas of needs in the communities and go ahead to initiate self-help projects that would meet these needs. The men's group and other Community Based Organisations are then informed and collective efforts are made in the implementation of the identified project. This practice is an age long tradition of the people of Enugu State and has enhanced community development efforts in these areas in the past.

Community development according to the United Nations in Oyebamiji and Adekola (2008) is a process by which the efforts of the people themselves are united with those of governmental authorities to improve economic, social and cultural conditions of community, to integrate those communities into the life of the nation and to enable them contribute to national progress. A more elaborate definition was given by USICA, in Onyeozu (2007), which described community development as a process in which social action is enforced thereby a group of people from the same community will collectively set goals and take actions in achieving the set goals. These set goals encompassed their common and individual needs, problems, make group and make plans to meet these needs and as well resolve these challenges with maximum reliance upon community materials and human resources as well as the government and other agencies outside the community 
This implies that when development programmes follow a process that ensures the active participation of the community people at every stage of the process it is referred to as community development. This process according to Oyebamiji and Adekola (2008) starts with needs assessment, planning, resource mobilization, implementation, evaluation and maintenance.

Planning in community development involves the identification or formulation of the objectives of a programme or project, the identification of needed and available human and material resources, mapping out strategies and procedures for the attainment of a programme objectives (Imhabekhai, 2009). Successful execution of community development projects depends largely on the quality of planning put in place before commencement of implementation. Like the first phase, planning in community development must involve all the stakeholders in a particular programme. In other words, the adult men, women, youths and their leaders must be involved in the planning process. Therefore, it is important that the people's customs and traditions are taken into consideration as this often determines whether or not they will be willing to be a part of this process. Effective planning ensures successful implementation of a development programme. Programme implementation is the actual execution of the project and this should be followed by monitoring and evaluation.

Customs and traditions play an indispensable role at every stage of this process. What people consider to be a need will be influenced by their traditions and customs. For example, in controlling population increase in a rural community using birth control measures, community people may resist such effort and not consider it a need if their customs and traditions see children as a gift that should not be rejected. This is the same in planning, resource mobilization, implementation and other stages of the community development process. It is against this background that this study critically examines the influence of customs and traditions on the process of community development among rural communities in Enugu State.

\section{Concept of Community Development}

Community development as a concept has enjoyed a wide range of definition since its introduction in 1948 at the Cambridge summer conference. However, the practice of community development has existed in most African societies long before its conceptualization. This view was supported by Anyanwu in Adekola (2013) when he noted that in Africa, community development is nothing new. He observed that from the earliest periods of human history, men have sought to improve their lots, and community development is only a modern way of doing this. Since the introduction of this concept, a number of definitions have emerged from various scholars. A careful examination of these various definitions reveals that there are some common elements that all these authors agree must be included in defining the term community development. Put differently, all the scholars are saying the same thing in different ways and context.

The Economic Commission for Africa in Imhabekhai (2009) defined community development as the outcome of a series of qualitative and quantitative change that occurs among rural population. Hence, it is a process in which a set of institutional, social, cultural and technical measures are put in place for the inhabitant of these rural areas with the sole aim of improving their socio-economical and socio-cultural conditions. Similarly, Ihejirika (2007) defined community development as the process by which the government and its people living in rural communities collectively put efforts together in order to improve the socio-economic, and cultural conditions of people as well as integrate their activities in nation building for overall growth and development of the nation. This suggests that community development emphasizes the collaborative effort of people with that of government or none governmental actors to improve the people's well-being. Putting this more succinctly, the Ashridge Conference on Social Development in Oyebamiji and Adekola (2008) defined community development was defined as a movement designed to promote better living for the whole community with the active participation and on the initiative of the community.

\section{Brief History, Customs and Traditions of Enugu State}

Enugu state is located in the south east geo-political zone of Nigeria. It has its capital city as Enugu. According to the 2006 census, the state has an estimated population of 3,267.837(1,596,042-males and 1,671,795-females. The state has three senatorial districts which are Enugu East, Enugu West and Enugu North with a total of 18 local government areas. Enugu East senatorial district consists of Enugu East, Enugu North, Enugu South, Isi-Uzu, Nkanu West, Nkanu East, Enugu North Local Government Areas. Enugu West senatorial district also consists of Aniniri, Awgu, Ezeagu, Oji River and Udi Local Government Areas. Enugu North senatorial district consists of Nsukka, Igbo-etiti, Uzo Uwani, Udenu, Igbo-eze north and Igbo-eze South Local Government Areas. (Wikipedia, 2012)

The predominant occupation of rural people in Enugu State is farming. There are two major remarkable seasons in Enugu State - the raining season, which enhances fertilization and growth of agricultural activities. Flooding is not frequent in the land or erosion that causes damages in the land. The dry season - this is also very important because it marks the harvesting period.

Onouha in Adekola and Nwoye (2016) noted that as it is with any other part of the Igbo land (Eastern part of 
Nigeria), Enugu State has numerous cultures and traditions that guide both the indigenes and non-indigenes. These traditions like any other existed before the advent of Christianity and they were basically handed down to coming generations orally. When Christianity came in, there were religious and culture crisis in the land. Every effort was made to ensure that people (indigenes) did not stray from the culture. Some of the customs and tradition in Enugu State as identified by Onouha in Adekola and Nwoye (2000) include the followings:

\section{- The practice of gender inequality:}

It is a common practice among the people of Enugu State to forbid women from attending or sitting in the same meeting with the men. It is believed that the man is the head of the house and should represent the interest of all members of his immediate family, that is, the wife and children. If the woman has opinions concerning certain issues of community or family concern, she must air her opinion only to her husband who decides whether or not such opinion is good enough to be discussed among the men in a meeting. It is also believed that since the men usually speak in riddles and proverbs, it is difficult for the women to comprehend such kind of discussions.

\section{- Belief in Deities:}

Communities in Enugu State like most traditional African societies believes strongly in the powers of the ancestors (spirits of the fore fathers). It is believed that these deities have some powers to guide the actions of the people and would punish those who stray from the set standards and norms. The Chief priest known as "Eze Nmo" or "Dibia Nmo" is usually seen as the mouth piece of the gods, therefore his judgments and decrees are seen as sacred and unalterable. Straying from them attracts grave consequences. (Onuoha, in Adekola, 2016)

\section{- The New Yam Festival:}

The celebration of the New Yam is a historical phenomenon in Igbo Land. It is the grand master of all other Igbo festivals. It is an annual reunion in Enugu State. It is an agent of social mobilization. All and sundry within the community come home from far and near and usually assemble at a scheduled venue for rituals and celebrations, its relevance in strengthening the bond of unity in the community has been recognized by various scholars. (Anikwe, 2012).

Okafor (2010) asserted that most Igbo communities require that the harvesting and eating of the new yam must be a matter in which the community as a whole must have a hand and input. Moreover, since the yam is about the principal crop in Igbo agriculture, the new yam festival marks the climax of the year calendar, so that it is both the beginning and end of year.

Arikwe (2012) noted that during the new yam festival, several Igbo traditions are practiced. One glaring example of Igbo tradition observed during the festival is respect to elders and seniority. During the festival, homage is paid to the eldest person in the village just in the Christian variant, of the festival homage is paid to the eldest priest in Enugu Diocese. Secondly, an Ozo title holder is respected in a gathering even if he is not the eldest. That is respect for achievement.

\section{- Oral tradition:}

In Enugu State, some streams in communities in this area cannot be fished on and modern mechanisms cannot be employed in carrying out any form of development programme around those streams. It is believed that if any form of project or fishing is done in those streams, the fishes will be sent away by the noise and the gods will dry up the stream. Some of these streams include the "Owerre ngene" stream in Amurri community, "Ogba -Agu" stream in Ihuna ekwe-agu autonomous community in Nkanu West LGA and the "Onu-Ogbu" stream in NaraUnateze community in Nkanu East LGA of Enugu state. This explains why it is a common practice in the Igbo custom for elders to offer prayers and say "Ndu-miri, ndu-azu, miri-atana, azu-awana" meaning "the waters should not dry and the fishes shouldn't die" (Onuoha in Adekola and Nwoye, 2016)

\section{- Women August Meeting:}

Most remarkable tradition among the people of Enugu State is Women Wing Meeting of town unions (Ogbako Umunwanyi August), which is popularly referred to as the "Women August Meeting". The women group which is also the women wing of every town union in communities in Enugu State is a very strong organization comprising of women within and outside the community including those in Diaspora. In fact, this organization has different branches scattered all over the country and outside the country. They hold periodic meetings to discuss issues bothering on the welfare and development of their communities. These various branches come together every month of August annually to hold a meeting in the community with the intention of carrying out development programmes in the community. This is what people popularly refer to as "August meeting". It is usually a very big event so indigent women of these communities within and outside the community come together, harmonize their different plans and projects. After identifying their priority project, they send delegates to inform and seek the approval of the men in their planned project and in some cases solicit their support in executing these projects especially when they are capital intensive. For example, the existing massive Ibute Community hall in Enuagu-Amurri town was initiated by "Nma Nwanyi Bu Di" the women cultural dance group through the process of the "August Meeting". This tradition which has been in existence for a long time is still upheld in Enugu State and undoubtedly promotes community development (Ogbuife, 2014) 
- The "Eke" market day and the Oriri-Ani Festival:

Among the Ibos including those in Enugu State, some days are held sacrosanct as no farming activity takes place (Eke market day). It is believed that Eke day is for the spirit and should not be defied as men and women are restrained from farms. The reason given was that to venture is to invite the wrath of the gods, as evil could befall any offender.

\section{- Hard work and Prosperity:}

Hard work and prosperity are very important values drawn from Igbo tradition and history. Names and philosophical statements show that the Igboman's adventure, enterprise, mental dexterity, economic search beyond one's community were not brought about by colonialism. Hard work and prosperity are two essential components of the Igbo value system. Hard work management, storage and saving were all required to attain the prestigious Ozo and other high-class associations and societies in Igboland.

\section{Influence of Customs and Traditions on Development of Rural Areas}

Traditions and customs play an indispensable role in the life of almost all African societies, especially in the rural areas where modernization may not be as pronounced as it is in some cities. These traditions and customs influence every activity engaged in by the people including development. It serves as a guide for what is to be accepted or rejected in the community.

This view was supported by Imhabekhai (2009) when he observed that if a change or innovation to be introduced to a community is at variance with the people's way of life (customs and traditions), they may perceive that change or innovation will cause adverse distortions in their way of life especially when the change or innovation is significantly at variance with the belief system, values and way of life. For instance, the campaign against female circumcision and genital mutilation that has been discovered to have health, sexual, marital and other hazards is still being resisted because most of the people who practice them believe they are part of their custom and traditions that must be preserved.

Deekor and Nnodim (2005) recounts a case of study in Ifakala community in Imo State on how traditions and customs have affected development. It was a case of holding tenaciously on traditional discrimination against a group of people by the other. In Igboland, the caste system is prominent (free-born and the outcast), and this has led to conflict, sometimes violent once disrupting or halting permanently some development programmes or projects.

In some communities, it is so strong that pupils from these two groups do not sit together in class or a priest regarded as an outcast allowed to pastor a church. Ukaegbu and Agunwamba in Deekor and Nnodim (2005) also recounted how a water project could not be executed in Ifakala in Imo State. This community has no good source of water supply. The government of the then Imo state saw the need to give them pipe-born water. The water project was approved and the contractor mobilized to site. Materials for the project were acquired and the project ready to take off when the news went round that one of the villages (Amafor) in which the project was to be sited was an outcast village, therefore, any water from their soil would not to be acceptable to the free-born. The project was halted. Five years later, an Amafor indigene through financial donations tried to kick start the project, but the people insisted that water drawn from Amafor-an outcast (Osu) territory was unclean for use. They did not only reject the donation, but that was the end of the

Similarly, Batten in Imhabekhai (2009) recounts the story of a change agent that introduced a very light and swifter paddle in a fishing community but the people rejected the new paddle, though better because they believe that the traditional heavier paddle is made from the wood of a tree that gave the people spiritual protection while fishing but the new paddle lacked such spiritual potency.

Furthermore, there have been situations and circumstances in Enugu where traditions and customs impede or disrupt community goal attainment, integration and developments programmes. For example, there is a situation where a vast expanse of land in a community in Nkanu-West, with great solid mineral potentials, is left laying fallow and wasting for years for reason that it is against the tradition and custom of the community to execute or carry out any developmental or economic activity on the land, even when potential investors have indicated interest to invest and carry out community development on such land, which will enhance and develop the community, is a good example to drive home our position on the impacts, albeit negative, of traditions and customs to community development in Nkanu-West Local Government Area of Enugu State-Nigeria, and it very common and rampant in these communities.(Anikwe, 2012)

A more recent event is an instance of a community in Nkanu-West which rejected the offer of a religious Organisation (a catholic church) to assist the community in building a technical institution where people can learn all kinds of skills. They insisted that the large expanse of land left idle for years was believed to belong to a particular deity (Chiokuke Chukwu-Abiama) which the people go to for healing when they are sick and this deity is highly revered by the people. They worship this deity during the new yam festival (Iriji). This community refused therefore to go into any agreement with the organisation and the project was cancelled.

The above instances clearly demonstrate how much adverse impact traditions and customs have had on 
development in Nigeria. It is very necessary therefore for a community development agent or other agencies carrying out development to take cognizance of the existing customs and traditions of a community while planning a community development programme.

\section{Statement of the Problem}

Community development emphasizes the principles of felt needs, participation and self-help. People's participation in community development process ensures community most pressing needs are identified, proper planning takes place and local resources are united with those of external agencies to meet the so identified needs. This gives the community members a sense of ownership of the project which means they will maintain such projects and sustain the effort.

Unfortunately, some community development programmes in Enugu State do not enjoy widespread participation of community members. Some programmes even face resistance from the people especially when such programmes do not conform with the people's customs and tradition. Tradition plays a key role in rural communities in Enugu State as in other places in Nigeria. People rejects a development programme, even when it is apparently for their own good, if such programme negates the people's customs. This has slowed down the pace of development in this area. It affects the planning, resource mobilization and implementation of community development in the study area. Exposure of such influences of traditions and customs on the process of community development among rural communities in Enugu State, is the problem of this study.

\section{Purpose of the Study}

The purpose of the study was to examine the influence of customs and traditions on the process of community development among rural communities in Enugu State. The specific objectives of this research are to:

1. identify the existing customs and traditions prevalent among the various rural communities in Enugu State.

2. ascertain the influence of existing customs and traditions on planning of community development programmes in Enugu State.

3. determine the influence of the existing customs and traditions on implementation of community development programme in Enugu State.

\section{Research Questions}

The following research questions guided the study:

1. What are the existing customs and traditions prevalent among the various communities in Enugu State?

2. What is the influence of the existing customs and traditions on planning of community development programmes in Enugu State?

3. What is the influence of the existing customs and traditions on implementation of community development in Enugu State?

\section{Method}

The research design adopted in this study was the descriptive survey design. The target population of this study was 379 traditional rulers and 468 town union presidents in all the 468 communities in the seventeen local government areas of Enugu State. Making a total of 847. No sampling was done as all 847 respondents were taken as a census. Data for this study were collected using two instruments- a self-designed questionnaire and Focus Group Discussion (FGD) guide. The validity of the instruments was determined by three experts. Two specialists in Community Development and one in Measurement and Evaluation. The internal consistency of the questionnaire was tested using Cronbach Alpha statistics. Reliability coefficients of $0.81,0.76,0.86$ and 0.79 were obtained from the various research questions in the instrument. The researchers administered and retrieved completed copies of the instrument to the respondents with the help of some town union presidents. Out of the 847 copies of the questionnaire administered, 840 were properly filled and used for the study. This represents $99 \%$ retrieval. For the Focus Group Discussions (FGDs), a total of four (4) sections were conducted with the traditional leaders from the local government areas sampled. The researchers sought the approval of the heads of traditional rulers council in Enugu State, Nigeria and had the session during their council meetings. Each section of the FGD comprised 7-10 persons and last between 70 and 80 minutes. Quantitative data collected through the questionnaire were analysed using mean statistics and standard deviation while the qualitative data collected through the Focus Group Discussion Guide were analysed using content analysis technique. Any question item with a mean score of 2.50 and above was regarded as "Agree" while items below 2.40 were tagged "Disagree"

\section{Results}

Research Question 1: What are the existing customs and traditions prevalent among the various communities in Enugu State? 
Table 1: Mean Response of Respondents on Existing Customs and Traditions Prevalent among the Various Communities in Enugu State

\begin{tabular}{|c|l|c|c|l|}
\hline $\begin{array}{c}\text { S/ } \\
\text { N }\end{array}$ & ITEMS & Mean & SD & Remark \\
\hline 1 & gender inequality (women are not part of key decision making in meetings) & 3.18 & 0.79 & Agree \\
\hline 2 & Strong believe in the powers of the ancestors (spirits of the fore fathers) & 3.14 & 0.78 & Agree \\
\hline 3 & $\begin{array}{l}\text { Celebration of traditional ceremonious event referred to as Iriji or Iwaji (the } \\
\text { new yam festival) }\end{array}$ & 2.85 & 1.03 & Agree \\
\hline 4 & $\begin{array}{l}\text { Celebration of an annual traditional event by the women wing of the town } \\
\text { union popularly referred to as "Ogbako Umunwanyi August "(Women } \\
\text { August Meeting) }\end{array}$ & 2.73 & 1.07 & Agree \\
\hline 5 & Observance of "Oriri-Ani" festival as no farming week & 3.29 & 0.82 & Agree \\
\hline 6 & The practice of "Ohu" (caste system) & 3.32 & 0.79 & Agree \\
\hline 7 & $\begin{array}{l}\text { The practice of not fishing or carrying out projects in certain streams in rural } \\
\text { communities. }\end{array}$ & 3.15 & 0.75 & Agree \\
\hline 8 & "Igede Eze" (Kings and noble men dance) & 2.88 & 0.66 & Agree \\
\hline & Grand Total & $\mathbf{3 . 4 8}$ & $\mathbf{0 . 8 4}$ & Agree \\
\hline
\end{tabular}

The result of the analysed data in 1 revealed that majority of the respondents in Enugu State agreed that the existing customs and traditions prevalent among the various communities in Enugu State are those listed in items 1-8 in Table 1. These items have mean scores that are above the criterion mean of 2.50 .

With grand mean scores of 3.48 , therefore, the answer to research question one is that the existing customs and traditions prevalent among the various communities in Enugu State are gender inequality, believe in the powers of the ancestors, the new yam festival (Iriji or Iwaji), "Ogbako Umunwanyi August", (Women August Meeting), Soil festival-No farming for traditional one week (Oriri-Ani Na Nso-Ani), practice of "Ohu" (caste system), practice of not fishing or carrying out projects in certain streams in rural communities and the belief in hard work and prosperity.

Research Question 2: What is the influence of the existing customs and traditions on planning of community development programmes in Enugu State?

Table 2: Mean Response of Respondents on Influence of the Existing Customs and Traditions on Planning of Community Development Programmes

\begin{tabular}{|c|l|c|c|c|}
\hline S/N & ITEMS & \multicolumn{2}{|c|}{} & \multicolumn{2}{|c|}{} \\
\hline 15. & \multicolumn{1}{|l|}{$\begin{array}{l}\text { Women are not allowed in certain decision-making process in the } \\
\text { planning of community development programmes. }\end{array}$} & 2.91 & 1.07 & Agree \\
\hline 16. & $\begin{array}{l}\text { The practice of "Ohu" prevents certain people referred as slaves from } \\
\text { sitting with the freeborn in planning of development programmes. }\end{array}$ & 2.20 & 0.45 & Disagree \\
\hline 17 & $\begin{array}{l}\text { Community development projects to be sited at forbidden areas are } \\
\text { rejected at planning stage. }\end{array}$ & 3.16 & 0.88 & Agree \\
\hline 18. & $\begin{array}{l}\text { A community development programme will not succeed if the traditional } \\
\text { leadership structure is not actively involved in the planning. }\end{array}$ & 3.13 & 0.86 & Agree \\
\hline 19. & $\begin{array}{l}\text { The "Ogbako Umunwanyi August" women August meeting is used as an } \\
\text { avenue for planning of community development programmes by women } \\
\text { in your community. }\end{array}$ & 3.20 & 0.92 & Agree \\
\hline 20 & $\begin{array}{l}\text { Traditional festival periods are taken into consideration when planning } \\
\text { community development programmes/projects. }\end{array}$ & 2.78 & 0.71 & Agree \\
\hline & Grand Total & $\mathbf{2 . 9 0}$ & $\mathbf{0 . 8 2}$ & Agree \\
\hline
\end{tabular}

The data analysed in table 2 revealed that items 15, 17, 18, 19 and 20 had mean scores that are above the criterion mean of 2.50 which implies that majority of the respondents agreed with all these items in the table. However, item 16 had a mean score of $2.20(\mathrm{SD}=0.45)$ which is lower than the criterion mean of 2.50. This implies that majority of the respondents disagree that the "Ohu" tradition (caste system) prevents certain people referred to as slaves from sitting with the freeborn in planning of development programmes.

With grand mean scores of 2.90 , therefore, the answer to research question three is that customs and traditions influence the planning of community development programmes in Enugu State by excluding women from the decision making process in planning community development projects, rejecting projects to be sited in places the people consider forbidden, avoiding planning of projects during festivals and using August meeting tradition as an avenue for planning of community development programmes.

Research Question 3: What is the influence of the existing customs and traditions on implementation of community development in Enugu State? 
Table 3: Mean Response of Respondents on the Influence of Existing Customs and Traditions on Implementation of Community Development

\begin{tabular}{|l|l|c|c|c|}
\hline S/N & ITEMS & Mean & SD & Remark \\
\hline 27. & $\begin{array}{l}\text { Traditional leadership structure promotes active participation of } \\
\text { community members during project implementation. }\end{array}$ & 2.66 & 1.05 & Agree \\
\hline 28. & $\begin{array}{l}\text { Through the "Women August Meeting", women within and outside the } \\
\text { community come together to initiate and execute development projects in } \\
\text { communities in Enugu State }\end{array}$ & 2.79 & 1.08 & Agree \\
\hline 29. & $\begin{array}{l}\text { The observance of "Oriri-Ani” festival results in economic waste in terms } \\
\text { of man-hour since no farming or development activity can take place that } \\
\text { week }\end{array}$ & 2.40 & 0.45 & Disagree \\
\hline 30. & $\begin{array}{l}\text { People considered as "Ohu or Osu" (Caste System) are not allowed to } \\
\text { participate in community development programmes }\end{array}$ & 2.31 & 0.44 & Disagree \\
\hline 31 & $\begin{array}{l}\text { All community development programmes are put on hold during long } \\
\text { festivals in your community. }\end{array}$ & 2.50 & 0.56 & Agree \\
\hline 32 & $\begin{array}{l}\text { Certain sacrifices are made before some community development projects } \\
\text { are implemented. }\end{array}$ & 2.40 & 0.50 & Disagree \\
\hline & Grand Total & $\mathbf{2 . 5 0}$ & $\mathbf{0 . 6 8}$ & Agree \\
\hline
\end{tabular}

Data analysed in table 3 showed that majority of the respondents agreed with item 27 that traditional leadership structure promotes active participation of community members during project implementation with mean scores of $2.66(\mathrm{SD}=1.05)$. They also agreed with item 28 that through the "August meeting", women within and outside the community come together to initiate and execute development projects in communities in Enugu State $($ Mean $=2.79)$ They further agreed with items 29, 30 and 32 as shown in their respective mean scores which are lower than the criterion mean of 2.50. This indicates that majority of the respondents are of the opinion that the "Ohu", Oriri festival and offering of sacrifices to deity do not really affect the implementation of community development programmes in Enugu State.

With grand mean scores of 2.50 , the answer to research question 3 is that the traditional leadership structure, August Meeting traditions and certain festivals are the customs and traditions that influence the participation of people in the implementation of community development programmes in Enugu State.

\section{Analysis of Focus Group Discussion (FGD)}

Theme 1: Opinion on "traditions and customs practiced by the people of Enugu State"

The participants identified some of the customs and traditions practiced in Enugu State to include, wrestling (Igba Mgba) festivals (Oriri), Adult circumcision (Ibe-Epi or Ibe-Ugwu) Masquerade (Mmanwu), Age grade grouping (Ulo-Ogbor or Otu-Ogbor), pouring of libation (Igor-Ofo), homage to the ancestral fathers' graves (Igba-Aju), the new yam festival (Iriji or Iwaji), the Women August meeting (Ogbako Umunwanyi August), Soil festival-No farming for one sacred week (Oriri-Ani Na Nso-Ani), Caste system ( Ohu or Osu), practice of not fishing or carrying out projects in certain streams in rural communities and the belief in hard work and prosperity. Some of the participants said:

"The people of Nkanu land like other communities in Enugu state do not joke with customs and traditions. Some of the traditions practiced here are the new yam festival also known as the "Oriri Anu"...Yam is regarded as the king of crops and is usually celebrated during the period" "New yam festival used to take place between the months of July-October while Ibeagwa in Nike Clan was the custodians of the traditions... Masquerading is also one of the traditional practices in my community. Other traditional practices are women August meeting, Ohu issue and not allowing women in their monthly periods to go to the streams"

"Some of the traditional practices being upheld now is the "Iriji"(new yam festival), the masquerade, the women's August meeting, etc"

"...traditions practiced in our communities include Aji, Anu Oha festival, the "Iriji," (new yam festival) the "Igba mgba"(wrestling), "Igor ofo"," Ibe ugwu" and so on".

"the Oriri iji or Iriji (new yam festival) is done in Onwa-Eno at Anu Nike shrine. In the festival there is usually drinking, eating and dancing"

Another participant said that:

"The "Ohu \& Amadi" practice is still there even though most of us are no longer comfortable

with it because God did not create anyone as an "Ohu" (slave)"

From the responses gathered, the participants agreed that there are some customs and traditions practiced by the people of Enugu State and these include wrestling (Igba Mgba) festivals (Oriri), Adult circumcision (Ibe epi/Ibe ugwu) Masquerade (Mmanwu), Age grade grouping(Ulo-Ogbor), pouring of libation (Igor-Ofo), homage to the ancestral fathers' graves (Igba-Aju), the new yam festival (Iriji or Iwaji), the August meeting, Oriri-Ani” festival 
(Soil Celebration), practice of "Ohu” (Caste system), practice of not fishing or carrying out projects in certain streams in rural communities and the belief in hard work and prosperity.

Theme 2: Opinion on "Influence of customs and traditions on the planning of community development programmes in your community".

All the participants agreed that customs and traditions influence the planning of community development programmes in communities in Enugu State.

A participant said that:

"The Igwe, the Cabinet and the town union work together in planning and siting development projects in a particular location.

Another participant said that:

"when planning for any development project, people are picked from each kindred. Those picked are responsible for informing their kindred and seek advice and suggestions from them"

A participant also said that:

"the Ulo-Ogbor (Age grade groups) most times are consulted in the planning of community development programmes in the community. They alongside the leaders and other people in the community are involved in planning of development projects"

A participant noted further that:

"It is difficult to embark on a project in our community without discussing the effects on customs and traditions. It will be difficult to convince the people to accept such projects"

The opinion of the participants in the Focused Group Discussion indicated that customs and traditions in communities in Enugu State influence the planning of community development in the study area to a large extent. Theme 3: Opinion on "Influence of customs and traditions influence the implementation of community development programmes/projects in your area.

The participants of the FGD were of the opinion that certain aspects of their customs and traditions actually influence the way development projects are implemented. For example, a participant said that:

"Those tagged Ohu (slaves) do not freely participate in carrying community development projects. They are not allowed to participate in such things as the "Igede" dance. This still exists in especially Nkanu Land."

Another participant said that:

"The women August meeting helps in community development. Whenever they hold meetings, they teach the rural women a lot, they even built a bus stop in the community

The participants further noted that libations are sometimes made to appease the gods before some development projects are carried out. A participant recounted a particular occasion where he had to do the appeasing of the gods. He said that:

" a project was to be sited in a place considered as an evil forest and I personally went to the forest and appeal to the spirit of the deity to relocate because a more important project was to be built on that site".

From the discussion of the participants, it was revealed that the customs and traditions of Enugu people influence the implementation of community development in the study area. Some aspects of these traditional practices influence community development positively while some influence it negatively.

\section{Discussion of Findings}

The findings of the study in research question one revealed that from the qualitative and quantitative data analysed, the existing customs and traditions prevalent among the various communities in Enugu State are (Igba Mgba) festivals (Oriri), Adult circumcision (Ibe epi/Ibe ugwu) Masquerade (Mmanwu), Age grade grouping(Ulo-Igbor or Out-Ogbor), pouring of libation (Igor-Ofo), homage to the ancestral fathers' graves (Igba-Aju), the new yam festival (Iriji or Iwaji), the August women meeting, Oriri-Ani" soil festival (no farming for one traditional week), practice of "Ohu" (Caste system), gender inequality (women not allowed to sit with men in meetings) and practice of not fishing or carrying out projects in certain streams in rural communities. This finding was supported by the findings of a study carried out by Adekola and Nwoye (2016) which revealed that some traditions and customs practiced in Nkanu West and Nkanu East LGAs of Enugu State are; the practice of gender inequality where women are seen as the weaker sex. Consequently, they are not allowed to sit in the tables of men in meetings as the men are seen to be superior. There is the common belief in the powers of the ancestors (spirit of the forefathers). The people believe that the laws and norms laid down by the ancestors are sacred and cannot be broken. Another notable custom of the people of Nkanu West and Nkanu East LGAs is the marking of the new yam festival (Iriji) and the women wing of the town union popularly referred to as women August meeting. Similarly, Nwachukwu (1997) identified the customs and traditions practiced in Enugu State to include the Iri ji (new yam festival), the Osu or Ohu system, the Igbo masks and masquerades etc. 
The result of the analysed qualitative and quantitative data for research question two showed that customs and traditions influence the planning of community development programmes in Enugu State by excluding women from the decision making process in planning community development projects, rejecting projects to be sited in places the people consider forbidden, avoiding planning of projects during festivals and using August women meeting tradition as an avenue for planning of community development programmes. The findings, however, revealed that the "Ohu na amadi" (caste system) practice does not really influence the planning of community development as this tradition is gradually going into extinction. This finding is supported by Ihejirka and Evans (2017) in the findings of their study which revealed that traditional institutions provides forum for the planning and implementation of community development projects which were aimed at providing basic amenities and assistance to the needy members of the traditional community.

The result of the findings of the analysed qualitative and quantitative data for research question three showed that traditional leadership structure, August women Meeting traditions and certain festivals influence the participation of people in the implementation of community development programmes in Enugu State. The traditional leadership system mobilizes human and material resources in the community for the implementation of community development programmes/projects. Similarly, the August meeting tradition also encourage women to be part of implementation of the project. The findings revealed, however, that in most communities, those considered as "Ohu" (caste system) are not really discriminated in the implementation of community development. This is similar to the findings of Batten in Imhabekhai (2009) who reported the incident of a change agent that introduced a very light and swifter paddle in a fishing community but the people rejected the new paddle, though better because they believe that the traditional heavier paddle is made from the wood of a tree that gave the people spiritual protection while fishing but the new paddle lacked such spiritual potency.

\section{Conclusion}

The study concluded that the customs and traditions practiced in Enugu State, Nigeria are (Igba Mgba) festivals (Oriri), Adult circumcision (Ibe epi/Ibe ugwu) Masquerade (Mmanwu), Age grade grouping(Ulo-Igbor or OutOgbor), pouring of libation (Igor-Ofo), homage to the ancestral fathers' graves (Igba-Aju), the new yam festival (Iriji or Iwaji), the August women meeting, Oriri-Ani" soil festival (no farming for one traditional week), practice of "Ohu" (Caste system), gender inequality (women not allowed to sit with men in meetings) and practice of not fishing or carrying out projects in certain streams in rural communities. These customs and tradition influence the planning and implementation process of community development programmes in the state. This influence is found to be both on the negative and positive, whereas certain traditional practices like the women August meeting, Age grade system, festivals, traditional leadership and ceremonies promote effective planning and implementation of community development programmes, other customs and traditions like gender inequality, Ohu (caste system) among others impede the processes in community development programmes.

\section{Recommendations}

Based on the findings of the study, the following recommendations were made:

1. Government and council of traditional rulers in Enugu State, Nigeria should organize sensitization programmes for community leaders to conscientize them on the need to eradicate certain customs and traditional practices that impede community development efforts in their communities. Since it was revealed that certain customs and traditions negatively influence community development in the study area.

2. Traditional rulers in Enugu State, Nigeria should engage all the organized traditional structure (women through August meeting platform, age grades and others) to do periodic planning of self-help development projects in their respective communities. Since these leadership structures are well respected in the area. This will reduce the reliance on help from external bodies which oftentimes are not readily available.

3. The council of traditional rulers in Enugu state should organize seminars and workshops for traditional rulers and other community leaders and educate them on the need to discard traditional practices that impede the implementation of community development programmes and encourage those practices that promote it. That way, most of these negative customs and traditions will be completely discarded.

\section{References}

Amirize (1998) Liberal education and community development. Port Harcourt: Osia Int'l Publishers Ltd

Amirize, B. (2007) Community Education in Contemporary Nigeria. Port Harcourt. Fio Press.

Adekola, G. (2013). Adult Education and Community Development. in B. A. Eheazu, C. N. Barikor, and I. S. Nzeneri (Eds). Readings in Adult and Non-Formal Educational Education. Port Harcourt: University of Port Harcourt Press. 77-91.

Adekola, G. \& Nwoye, C.E. (2016). Traditions and customs in community development: The case of Nkanu West and Nkanu East Local Government Areas of Enugu. Nigeria. Journal of Education and Practice, 7 (18), 120 - 
127.

Crossman, A. (2018) Customs: Their importance in Society. Retrieved from www.thoughtco.com/customdefinition-3026171. Accessed on $10^{\text {th }}$ September, 2019.

Green, T. A (1997). Folklore: An encyclopaedia of beliefs, customs, tales, music, and art. ABC-CLIO. pp. 800-. ISBN 978-0-87436-986-1. Retrieved 5 February, 2015.

Gideons, A. (2003) Runaway World: How globalization is reshaping our lives. ISBN 9780-415-9448-8 Retrieved on September 8, 2019 from https://en.m.wikipedia.org/wiki/tradition.

Ihejirika, J.C. (2007). Fundamentals of Adult Education and Community Development. Uyo: Abigab Associates Publishers Ltd.

Imhabekhai, C. I (2009). Management of Community Development Programmes and Projects. Benin: Uniben Press

Ihejirika, J.C. and Evans, O. (2018) Influence of traditional rulers in resource mobilization towards community development projects in Rivers State. International Journal of Innovative Psychology \& Social Development 6(2):98-112

Oyebamiji, M.A. \& Adekola G. (2008). Fundamentals of Community Development in Nigeria. Port Harcourt: University of Port Harcourt Press

Onyeozu, A.M (2016). The Concept of Felt-Needs in Community Development. Port Harcourt: University of Port Harcourt Press.

Wikipedia: The Free Encyclopedia.(2012). Accessed on 10/02/19 retrieved from en.m.wikipedia.org/ 